\title{
Chinese Traditional Governing Approach: An Analysis from Ancient to Mao Zedong Politics
}

\author{
Maria Muhtar $^{1}$, Tatheer Zahra Sherazi*1 \& Riaz Ahmad ${ }^{2}$
}

1. Taxila Institute of Ancient Civilisations, Quaid-i-Azam University, Islamabad, Pakistan.

2. Department of Politics \& International Relations, International Islamic University, Islamabad, Pakistan. 3. School of Public Policy and Administration, Xi'an Jiaotong University, Shaanxi, China.

\begin{abstract}
The study focuses on the traditional Chinese political culture and it discusses a multitude of rhetorical practices in imperial China. Simultaneously, it investigates the societal norms which alter daily, to fit with the ever-changing global politics. For these purposes, the traditional philosophies are studied, and the most prominent school of thought Confucianism has been discussed thoroughly. This research is an analytical, descriptive study written in the historical context. While tracing back the nature of political culture, it has been found that it has deep roots in the state and society since the ancient times however, is still relevant for the contemporary politics of China. At the same motive, it can be concluded that current Chinese system seems probable to persevere for many a long time to come. This study is fragmented into three portions; first element makes imperial Chinese politics and its problem; the second portion brings governance and politics of cutting-edge China under the lens; and the final and third portion gives the comparison of each and the findings garnered from this study.
\end{abstract}

Keywords: Chinese Politics, Chinese Governance, Chinese Ancient Politics, Traditional Chinese Politics, Chinese Traditional Governance, Mao Politics.

\section{Introduction}

The research begins from the study of an ancient China to the Moa's Communist China where the Chinese character is explored to gauge whether the Chinese were power oriented in terms of the power culture or were libertarians focusing on their personal freedoms and liberties like the Romans or the Greeks. Since without a healthy comparison, it is impossible to comprehend, whether it is the Chinese character overall and not the particular revolution which brought about this closeness and introvert attitude in China. To understand the role of ancient or traditional Chinese political culture, traditional philosophies are studied in depth and for this very reason the most prominent school of thought Confucianism has been discussed thoroughly. Confucian values of social hierarchy, family authority, and emphasis on public rituals and morality of individuals have become operative principles of Chinese political practices. The three most influential Confucian philosophers are Confucius, Mencius, and Xunzi. Confucius (551-479 B.C.E) lived in the time of political transition from an orderly society of Zhou dynasty (approx. 11th -8th centuries B.C.E) to the chaotic period of the SpringAutumn and Warring States. Thus, Confucian discourse is in response to the tumultuous times in which he is living. The ideal political model for Confucius is that of the Zhou dynasty where 
the ruler is benevolent, people are filial to their parents and loyal to their rulers and friends, the society respected authority.

Further in order to understand the proper context and nature of traditional political culture of China, there is need to apprehend the overall the nature political culture, its meanings and denotations. The power-culture concept utilized by other social scientists to convey their meaning or their interpretation of the use of power and its manifestation as a separate culture, thus, the creation of a power-culture. To name one such person, one can write Paul Kivel's name down. Paul Kivel wrote about power-culture in the perspective of sociology and his work is a brilliant explanation of power-culture. He explains power culture as the culture of the group, which has become more powerful compared to the other based on numerical value. He exemplifies his stance through a situation where a person from a different set of beliefs enters in an area dominated by the adherents of some other belief. He explains that the agitation, the person who has just arrived feels actually the result of the power culture or in other words, it's the stimulus, which tells that the power has a different culture. Still further, simply as the existence of the power-culture he resides on the fringes because the centre is occupied by the adherents of the other set of beliefs. The new arrival feels threatened because he does not conform to the values of the majority body and since the majority; body is powerful so he is at their disposal since they can behave with him in whatever way they like. In a simple way, political culture is the culture of ruling elite group in comparison of an individual.

This research sheds a light on the fact that how declamatory characteristics of communist Chinese politics are similar to the attitudes of Chinese people during different periods in Chinese history by highlighting the personality worship or especially the godlike reverence the people hold for their leaders-which manifest in their day to day business, the almost cult like practices and customs both moral and ethical which have been subscribed by the Chinese while attending to their sovereigns and the extensive use of similes.

\section{Theoretical Framework of Traditional Approach}

Though since the ancient times, there are several sects and denominations in China, none has exercised more influence over the political discourse than Confucius. He stressed upon a certain set of moral code which according to him is the best suited for an everlasting peaceful society. The moral code he espoused stressed upon individual morality, observing societal customs, respecting social frame work and family hierarchy. It is evident that Confucius taught his followers to respect the authority. The supreme theme in his teaching is of conformity that is by respecting the values, codes, customs, rituals and traditions one can live in peace. It also explains that Confucius disapproved anarchy or for that matter any anarchic theme disseminating from any political move. Over the years these very teachings of Confucius became the beacon house for the political system in China.

Confucius opened his eyes in the ancient China during the closing years of the reign of Zhou dynasty. Nevertheless, he had seen the peaceful time of the Zhou period just before the dynasty began to crumble and eventually give into the anarchy, power struggle, and the lawless period which usually precedes the switching of dynasties. Thus, he experienced the peaceful times as well as the turbulent ones which followed the fall Zhou period. In historical perspective he experienced the shift from Zhou dynasty to the Spring-Autumn period in China. SpringAutumn period is the period of power struggles political intrigues, confusion, anarchy, and chaos. Since he had adequate knowledge of the peace times too, he due to the virtue of his 
experience of the both times formulated his code. He regarded the Zhou period as the best. Therefore, as a reference point of the model state he regarded the Zhou period. This period depicted a picture of a land where the sovereign was held as if a deity and the sovereign equally held the whims and wishes of his subjects most high, the elders were respected and the family system was well knit. So, Confucius regarded these qualities as integral requirements for a peaceful and everlasting society.

The basic philosophy underlying the ideals provided by Confucius is moral and ethical romanticism. According to him a perfect society could be achieved if there are a certain virtues and customs. These virtues are represented by ren and $l i$ :

a) Ren translates into abstract qualities like loyalty, compassion, solicitous, and allaround goodness;

b) $L i$ means the codes, customs, conventions rituals and practices.

Confucius believes good governance is only possible when there is a delicate balance between both of these that is the ruling class adheres to ren and the subjects follow li. Another comprehension of ren and $l i$ would be -in Confucius's own words- "A good government leads the people with virtue and restrains them with ritual..." (Leys, 2.3, p. 6).

Confucius considered the sovereign as the great patriarch and the population his issues thus he believed that a leader should possess all the virtues possessed by a father as he is dealing with his children. Even more so Confucius considers the ruler as the ultimate hero for the population the ultimate guide. His all actions are awe-inspiring and worth copying and imitating. It can thus be said that Confucius considers that if the ruler is just the subjects will be just; no one would dare to break the line if the leader himself is observing the discipline. In Confucius's own words "If you steer straight, who would dare not" (Leys, 12.17, p. 58).

Confucius further explains to test the authority of the leader remains unchallenged the leader must bind his population into different rituals and actions so that the population in performing their role one feels as a part of the government and two exhibit their loyalty in performing what is asked from them about this too Confucius speaks "You must draw them (the masses) to you by having them perform the rituals for you" (Leys, 16.1, p. 81). This entire theory of the Confucius can be called as the renzheng or the benevolent government.

Another vital idea of Confucian political theory is Zheng Ming (amendment of names). The term was first instituted by Confucius who believed that the abuse of words and their implications were the immediate reason for social issues and discord. In his view, when names are not called right, discourse won't be fitting; when discourse is not proper, errands won't be proficient; when assignments can't be refined, ceremonies and music won't thrive; when rituals and music don't prosper, discipline won't legitimize the wrongdoings; when discipline does not legitimize the violations, the ordinary citizens won't know where to put their hands and feet" (Leys, 13.3, p. 132).

Here, Confucius called attention to the vital part of correspondence in contributing or restraining social request and proposing amendment of names as a political answer for the issue of confusion and ambiguity. The way toward correcting names should first begin at the social levels, "Give the master a chance to be a ruler; the subject a subject, the father a father, the 
child a child" (Leys, 12.11, p. 57). The errand of the state rulers was to guarantee that everybody plays out his or her part in the public arena. Further, the rulers must recommend another arrangement of social standards and good standard through amendment of names or production of new terms. Such a procedure, as per Hall and Ames (1987) would have a transformative impact in giving "the stimulus and bearing for social and political change" (p. 273). This philosophy Confucius shared with Greek Sophists who too believed the effect of language on the social conduct of the people.

Another great philosopher of the ancient China is Mencius born in (395 B.C.E) and died at 305 BCE. Menicus was an admirer of Confucius and therefore subscribes the Confucian political thought fully. He goes on to add into the concepts already given by Confucius. He made ren the focus of his study. He argued that the previous great dynasties got the power because they practiced good governance and believed in the ideals as provided by Confucius the philosophy of renzheng in point. He argued "Xia, Shang and Zhou dynasties prevailed by practicing renzheng and when they disregarded the principles of renzheng they fell out of favor and were replaced by being overthrown or by natural calamities" (Mengzi, 4.3.p. 153). This way Mengzi argues that it is the moral character of the ruling class which gives an assurance for the continuity of their rule.

Another assertion can be made by carefully analyzing Menicus's observation and that is there is somehow a divine right or a divine code in renzheng which if violated would cause the dynasty to be brought down, overthrown or destroyed by a natural disaster. This way Menicus get his idea sanctioned by yet another political theory of China and that is Tian Ming meaning 'divine instruction'. In other words, it is the Chinese version of the theory of divine right. Menicus's assertions were basically discussing the character of the ruler and the ruling class aristocracy and nobility. The dynasties mentioned above remained in power as long as they were considerate towards the people and watchful of the affairs of the people and they were replaced when they became harsh and headstrong and pleasure loving.

Xunzi (298-238 B.C.E), another great Chinese philosopher of Confucius school worked on the concept of $l i$. He argued that without rituals a society is a dead society. He goes on to proclaim that the rituals should be regulated by the sovereign. Thus, it can be said that Xunzi actually gave the idea of social control rather than merely pointing out the importance of rituals $\mathrm{He}$ actually elucidates the need to control the humans. He believed that $l i$ is a mechanism of keeping social balance by maintaining social hierarchy, avoiding discord and correcting anyone who breaks the line. Xunzi remarked "A man with no ritual will not survive and a nation without rituals will not find peace" (Knoblock, 2.2, p. 135). The idea of $l i$ transformed from purely ritualistic basis to an inventive method of controlling the people. Xunzi's ideas were adopted and thus have manifested periodically throughout the Chinese history thus having attained the status of a permanent aspect of Chinese politics. It was the same concept of Xunzi which came to surface in times of Sun Yatsen and Deng Xiaoping (Twohey, 1999). His ideas were further expanded by Han Feizi in a new direction.

Han Feizi was the student of Xunzi born in 280 B.C.E and died in 233 B.C.E. He believed in the evilness of human nature and thus argued that if there is no pressure to follow the line the humans would not follow it. Thus, he began the legalist school by proposing $f a$ that is penal code. Laws he said must be instituted and must apply to all but the sovereign because he is the representation of the state. Liang Chi-Chao exclaimed that the legalists had no faith in human liberties rather they believed in the government's authority to make peace. A relevance of 
Hobbes's ideas can be seen. Han believed in a very well disciplined and almost fluid participation of the people in the rituals as ordained by the ruler. Legalist school is least concerned to order the private lives of the citizens rather it busies itself in ordering the collective lives in obeying to the authority (Ames,1983). Though the legalist school gave a very gloomy and dry picture, it too was quickly adopted, periodically it too surfaced and it too was adopted by certain leaders of the ancient, imperial and contemporary China. Qin kings of the imperial China and Mao during the Cultural Revolution serve excellent examples.

In reality, there are numerous articulated speakers, discourse occasions and influences occurring in old China recorded in various chronicled and abstract works. Here, research will concentrate on three parts of logical practices:

a) Scattering of Zhou Li (The Rites of Zhou);

b) Talks in Shang Shu (The Book of History); and

c) Enticing interests of you Shui (Voyaging Persuaders).

A portion of the tenets are implemented like corrective laws and straightforwardly focused on social aberrance. A case of Zhou Li goes:

Death to any individual who bothers the government by starting changes; passing to any individual who befuddles individuals by influencing vulgar to clamor, wearing uncouth garments, displaying odd abilities, and utilizing odd utensils; Death to any individual who confounds individuals through adherences to wrong doings, contending for fallacy, considering strange considerations, and opposing specialist; demise to any individual who confounds individuals by honing witchcraft, crystal gazing, and fortune telling (Wu, 1984, p. 37).

By this law, the right to speak freely, think freely, and right to move about were totally precluded in Zhou tradition. Individuals would be compelled to adjust to such standards inspired by a paranoid fear of losing their lives. Moreover, Zhou Li was the center content for examinations in the determination of neighborhood authorities, acquaintance of Zhou Li is a characteristic of the higher learning and social elites. According to Peng Li's examination, in the principal month of each new year, high positioning authorities would spread substance of Zhou Li through oral and composed declarations. The neighborhood authorities would visit each area and group under their locale to clarify and advance comprehension of messages in Zhou Li.

Many other texts of the same period have the eloquent persuasive style and expression. This can thus be asserted even in pre-Qin China the persuasive writing was well in fashion. It is also a fact that such style was employed mostly by the elite and the nobility but it was very much in use. Further the existence of ancient scribbling containing flowery verbose, effective rhetoric and coherent persuasive pieces written by either the travelling persuaders or the other intelligentsia indicate one thing loud and clear and that is the ancient Chinese knew well the persuasive writing expression and they very well believed that good and effective communication is vital for smooth state craft.

There are certain important ethics among the popular ethics, which are the recurring themes in Confucius's analects. Since the centuries, China is following these traditions which involves: 
- Rén (仁, benevolence, humaneness);

- Ľ̌ (礼; 禮, proper rite);

- Yì (义; 義, righteousness or justice

- Xiào (孝, filial piety);

- Zhōng (忠, loyalty);

- Xìn (信, integrity)

- Zhì (智, knowledge);

- Jié (节; 節, contingency).

Having ones, work preserved is one thing and then having a team of the students to take forward one's work is a whole lot of different ball game. Then imagine having a team of committed scholarship to add on to one's legacy is actually, what is required to keep one's teachings alive for so long that they endure multiple millennia. Confucius nailed it and all without ever expressing any desire for such a success. No doubt from the time he began teaching and to the instance in which this scribe's fingers depart from the keys, after every stroke to jot words detailing and describing how the work of the grand master has a profound impact on the Chinese is a testament to the success of this sagely master. But along with the teachings and his analects; his students and the students of his students and all those who were inspired by him including the lowly and the rulers, too were important contributions of his. One can rightly say the material produced by his disciples too was actually partly a credit of the old master if not in its entirety.

These all constant themes of the Confucianism are common almost in all the versions or if considered distinct then pretty much in all of the Chinese religions. However, the grand master Confucius did the initial codification of these virtues in the Chinese background. These ideas are not necessarily Confucius's own inspiration but are perhaps the ideas, which Confucius merely compiled, or rather collected from the previous religious ideas. In practice, this says on Confucius's own authority since Confucius says that in many places in his analects that he is only a transmitter who transmits all that he has learned from the previously transmitted. Therefore, there is no strict copy right in any of the teachings and there is neither any strict copy right in any of the other Chinese religions. In addition, any barrier that they couldn't profess faith in any of the particular teachings of the other faith, as long as the primary difference remains intact the professor of the faith can have as many faiths as he likes. Therefore, the ideology of the previous religions is just as valid for Confucius save certain ideas with which the grand master had a logical disapproval. The way Confucius subscribed and retransmitted the earlier ideas and doctrines the later ones took Confucius's ideas and subscribed to them even having professed separate or different faith all together. This means these ideas are here to stay and practically assimilated into the Chinese social fabric practically becoming a defining characteristic of the Chinese populace.

Confucius's political ideas did receive criticism and it will not be wrong if stated that all the criticism the old master ever faced is solely due to his ideas about the politics. The ethical ideas he proposed are so global and natural that even the bitterest of foes of him has nothing against his ethical teachings. In the political sphere too, the old master found room for the dynasties of the past the Shang and the Zhou. His political ideas are not revolutionary of any kind but were reiterations of his moralistic code in the realm of politics. For example, "Confucius did not believe in the concept of "democracy", which is itself an Athenian concept unknown in ancient China. However, Confucius's principles can interpret that recommending against 
individuals electing their own political leaders to govern them, or that anyone is capable of self-government. He expressed fears that the masses lacked the intellect to make decisions for themselves, and that, in his view, since not everyone is created equal, not everyone has a right of self-Government" (Schuman, 2015).

\section{Research Methodology}

The current inquire about is qualitative and descriptive in nature where the accessible information and data within the substance are fundamentally assessed. The information is collected through auxiliary sources. Auxiliary information incorporates different books, magazines, experts' discussions, research articles; websites, and daily papers. A historical, descriptive method has been utilized in order to create a link between the ancient traditional political culture and the contemporary political culture. Here all the significant features of Confucius philosophy are discussed in order to find the role of authority on the current era. Later on, analysis of the connection of philosophy on political culture has been made to infer the future relevance.

\section{Traditional Approach of Chinese Governance in Contemporary Era}

Both Confucian and the communist politics share many ideals; both the systems work on the principles of hierarchy, both required involvement of the people with their participation in different rituals and processions and both required the individuals to believe in an ideology and a moral code. In his work "Spirit of Chinese Politics" Pye exclaims that the traditional Chinese politics share so much with the contemporary politics that it can be very careless a remark that communism in China was a completely new political agenda. Pye in his own words said:

The centrality of hierarchy, the elaborate concerns involved in managing superior-subordinate relations, and a pervasive use of moralistic rhetoric have combined to produce in China a form of Confucianist Leninism.... (p. ix).

There is another comparison made by Townsend and Womack, while comparing the politics of the two eras of Chinese politics reflected sister views to what Pye has propounded earlier. The gentlemen said: "the tendency to cast political discourse in terms of historical events and personalities did not die with the end of the imperial system in 1911. Despite marked differences in vocabulary and interpretations required by a Marxist approach, the Chinese Communists remain highly sensitive to the political uses and implications of Chinese history and have continued to find legitimization in China's past for the domestic and external developments of her most recent present" (p. 30). Assertions, both made by Pye and Townsend and Womack are held true since the pattern of politics in China is a living and growing testimony to these assertions.

Ancient China and imperial China both were pretty much in line with the thought of Confucius. It was communism which brought the completely new ideology to the Chinese in the era of Cultural Revolution in the year 1949. Cultural Revolution, prima facie changed the dynamics of Chinese politics thus if we manage to prove that even in the age of Cultural Revolution China retained much of its earlier political frame work then it means what we propose is accurate. And to make, what we propose bullet proof we will check it on yet another political 
and ideological shift in China relatively more modern shift and that is moving away from idealistic approach of Chairman Mao to the pragmatic approach of Deng Xiaoping. A set of four features has been singled out that will guide the research to reach our conclusion these four are: leader worship, moral preferences, rituals and the language expression.

\subsection{Leader Worship}

Almost all civilizations and all political organizations have entertained a certain belief of 'divine right'. This idea of divine right which has many facets, the most prominent one without doubt is the leader is the sovereign or the ruler has God like attributes only if he is not the God. And when the leader has such a persona then no doubt the entity is worshipped. An utmost devotion is reserved for the leader. The leader can so much so with a snap of his fingers decide the fate of his subjects. In ancient and imperial China, the leaders were no doubt worshipped as if deities but the interesting thing is the Chinese held this tradition even after the closing of the imperial era or should we state the practice of the leader worship lingered on into the modern age.

Chairman Mao Zedong was regarded as the God incarnate. Mao was attributed with super natural powers. He was considered the "savior of the people" and many other things like it. He was taken to be the "sun for the Chinese". Chairman was mentioned as "the light in our heart"; "the greatest teacher, the greatest leader, the greatest commander, and the greatest helmsman" of the Chinese. The worship of Chairman Mao intensified in the years of the Cultural Revolution. "Long live Chairman Mao;" "Wish Chairman Mao a long life," were just some slogans that were heard almost everywhere. This was the talk of the popular slogans and statements praising Mao, there were songs too written in praise of Chairman Mao for example the one noted below:

"The East is red, the sun rises.

China had Mao Zedong.

He seeks happiness for his people; and he is people's savior."

Every other song written in praise of Chairman Mao, brand him as Godly figure. Distributor of wealth, promiser of prosperity, giver of happiness and most of all worthy of all worship these are some common titles attached with Mao in songs. Now we see that even the distance of dozens of centuries could not change or alter the course of Chinese political attitudes. Mao was worshipped in the same way as those, the original ancient all-powerful kings were worshipped. Similarly, like Chairman Mao his successor Deng Xiaoping was worshipped. There were many titles of considerable praise given to him; the most popular was "the architect of China's success." Books are written, songs composed and movies produced to popularize the leaders thus they are taken to be worshipped and revered.

\subsection{Moral Preferences}

Chinese civilization is no doubt amongst the world's oldest civilizations and it has no doubt a plethora of mannerisms and etiquettes. These practices governed the day-to-day behavior of the people, how they transacted business and dealt with their chores. It is these etiquettes with time ingrained into the Chinese thinking and matured into the behavior of the Chinese. For instance, the principle of Tian Ming which meant "Mandate from God" was used excessively by every usurping force which overthrew the earlier regime. The very first argument by the 
new king or leader or ruler was simply that his taking over was justified on the basis of Tian Ming. Even Mao who in order to install the communist fabric came out very hard on Confucian ideals had to employ the moral code of ren. The propaganda mechanism adopted by the communists exploited heavily the moral code of the Chinese.

The Chinese moral code demanded the worship of the ruler as explained in the earlier portions of the study. Therefore, to no surprise Mao was revered and worshipped his red book was regarded as the bible of wisdom. He was in fact regarded as the Confucius of the modern times; his words were noted as quotations as were Confucius's. Deng Xiapoing's writings and speeches were similarly collected and published. Every high official is expected to have gone through Xiaopings's literature. Learned and knowledgeable in China are those who are well versed in the writings and literature of Chinese leaders. The utilization of moralistic dialect is as yet the focal element of Chinese political correspondence as in the instances of censuring Taiwanese leaders for their slant of Taiwan freedom, crackdown of Falun Gong, and with allegation that American authority they want to establish. Despite the fact that in private settings, individuals can transparently express their distinctive perspectives on these issues these days, in broad daylight circumstances, it is basic the individual relate to the expert in political perspectives and act in concurrence with the rendition of reality given by the administration (shangtong).

Rituals; like explained earlier there are songs specially sung in praise of the leaders. Accompanying these songs are special dances called the "loyalty dances." These dances fit the bill to be referred to as rituals. Since rituals are specially choreographed moves in order to pay homage to Gods or the superior entities. Thus, the practice of rituals too exists in this age which initiated in the Confucian age. Then there are many other practices which fall in the ambit of rituals like shouting of slogans before the meetings and ceremonies for example the intense shouting of slogans before and after Mao's speeches. Hsia (1972) observes that "Many Chinese villages have dedicated rooms of loyalty to the ideology of Chairman Mao and that many peasant households have their own 'tablets of loyalty.' These are clearly derived from the ancestral temples and tables of the old China: mornings and evenings the villagers gather, either in their communal room, or in front of their family tablets, to pay reverence to Mao Tse-tung [Mao Zedong]" (p. 233). There is another type of ritual too and that is obeying the commands, may you subscribe to the act or not if a superior order it the transaction must happen. And then there is another ritual relating to the dissemination of the information, whenever the government implements any new reforms or policy it is not shared with the public rather it is only given to top brass leadership thus solidifying the bureaucratic rule.

\subsection{The Use of Similes}

The utilization of allegories is a repeating logical system in traditional Chinese artistic and political writings. Weapon allegories and creature similes are especially prevalent in Zhan Guoze. The idea of pi (similies) was authored by Hui Shi (380-320 BCE) who characterized it as "utilizing what individuals know to pass on and clarify, of what individuals don't know" (SY 11.8.471). While similitude is a viable influential gadget in traditional Chinese social and political setting, representation utilized as a part of pubic talk amid the Cultural Revolution for the most part served to dehumanize "class enemy," to heighten scorn, and to incite savage act. Like the sorts of allegories in the traditional writings, war illustrations and creature similitudes were inescapable in dazibao. 
The Cultural Revolution was portrayed as "the fifth battle" propelled by Mao following different crusades in the historical backdrop of the CCP against Japanese and the nationalists. The distinction in philosophy amongst Maoists and hostile to Maoists was considered as a "fight" between genuine progressives and business people or revisionists. Genuine progressives must "assault and go for revisionists." Mao's mandates were named as "vital arrangement" that would "execute class foes into pieces" and "destroy their lines" (Tan \& Zhao 1996, p. 410). The motivation behind the Cultural Revolution was to "pick up an intensive triumph." To do as such Red Guards must "fearlessly and perseveringly battle against class enemies" and "promise to battle to death in shielding Chairman Mao and in safeguarding the communist headquarter" (p. 411). "There will be no withdrawal of officers without an exhaustive triumph" (p. 172). The other gathering of analogy dehumanized "class foes" by calling them "bull, phantoms, snakes, and devils" Wang Guangmei, spouse of Liu Shaoqi (the President of China amid Mao's time) was depicted as a "beast," "appealing lady," "dirty miss," and "snake" (p. 239). The individuals who have diverse perspectives from Mao were called "a gathering of snakes and puppy party" (p. 153).

Once in a while the war analogies and creature illustrations were utilized together. In one of the declarations by Red Guards, they composed: Now we should fire at the free enterprise running puppies, the bull, phantom, snakes, and evil spirits. We should focus at the deposit of old belief system, old culture, old custom, and old propensity. We should crush down anything that does not comply with Mao Zedong's idea (p. 36). Such dehumanization using similes looks like intently to the dialect principles of Nazi Germany in the support of the holocaust of six million Jews.

\section{Conclusion}

The traditional political culture in China is not new; it stuck with the Chinese from the day the Shangs impressed upon the people that their king is the one chosen by the heavens (the gods). Thus, his word is the final authority and when the Shang replaced by Zhou, they got their sanction from the god and claimed Shang has lost the confidence of the gods and so on. It concludes that while inquiring about the political culture of China, it has surfaced that the territories in which the public involvement was more, the people there have realized the fruits of their voice. The territories under reference are Hong Kong and Macau. Excluding these territories, the rest of China is power culture-oriented society where the man Mao still worshipped as a deity. If not more, considering that, he was anything but a bold politician who in his grand scheme of industrialization, hesitated not for a minutest second to cause the death of millions of Chinese, who worked to death and of the famine, in the work camps, as a result of disastrous economic policies.

Xi however, does not shy away from accepting the fact that they (socialist party of China) have after all capitalized upon the power culture. Due to the virtue of being on the top and with hardly any opposition from within the premiere, knows the best for all the resources are under his grasp, can do for the people of China the very best he can do. It can assert that the Chinese have now somehow put behind them the inherent issues of democracy and have along with them the benefits of the dictatorship. With the country, the workhorse of the entire world, there is no way that this power culture of China is going to falter anytime soon. Until some weaknesses emerge, some new fault lines become bolder to confirm Ibn-e-Khaldun's philosophy of cyclic brilliance of the civilizations. This Chinese model seems likely to endure for many years to come. 


\section{References}

Ames, R. (1983). The art of rulership: a study in ancient Chinese political thought. Honolulu University of Hawaii.

Arendt, H. (1964). Eichmann in Jerusalem Harmondsworth. Penguin.

Chan, A. (1985). Children of Mao: Personality development and political activism in the red guard generation. University of Washington.

Chen, L. (Forthcoming). Revolution and us: A cultural rendition of political movements in contemporary China. In X. Lu, W. S. Jia, \& R. Heisey (Eds.). Chinese communication studies: Contexts and comparisons. Westport, CONN: Ablex.

Confucius, (1992). Lun Yu bai-hua jin yi [The translation of Analects] Guo Chenyi and Li Yadong (Eds.). China Books.

Grump, J. I. Jr. (1964). Intrigues: Studies of Chan-kuo Ts'e. University of Michgan.

FitzGerald, C. P. (1976). Mao Tsetung and China. London: Hodder and Stoughton. Garrett, M. (1991). Asian challenge. In Sonja Foss, Karen Foss, and Robert Trapp (Eds.), Contemporary perspectives on rhetoric. Prospect Heights, ILL: Waveland, pp. 295306.

Garrett, M. (1993). Classical Chinese Conceptions of Argumentation and Persuasion. Argumentation and Advocacy, 29, 105-115.

Garrett, M. (1993). Classical Chinese Conceptions of Argumentation and Persuasion. Argumentation and Advocacy, 29, 105-115. https://doi.org/10.1080/00028533.1993.11951559

Gudykunst, W. B. \& Ting-Toomey, S. (1988) Culture and Interpersonal Communication. Sage. Hall, E. T. (1959). The Silent Language. Doubleday \& Company.

Hall, D. \& Ames, R. (1987). Thinking through Confucius. State University of New York.

Hsia, A. (1972). The Chinese Cultural Revolution. Orbach \& Chambers.

Jensen, Vernon (1992). Values and Practices in Asian Argumentation. Argumentation and Advocacy, 28, 155-166. https://doi.org/10.1080/00028533.1992.11951544

Kincaid, D. L. (1987). (Ed.). Communication Theory: Eastern and Western Perspectives. Academic Press.

Knoblock, J. (1988). (Trans) Xunzi: A Translation and Study of the Complete Works (Vol. IIII). Stanford University. https://doi.org/10.2307/1399771

Kroll, J.L. (1985-1987). Disputation in Ancient Chinese Culture. Early China, 11-12, 118-145. https://doi.org/10.1017/S0362502800003989

Leys, S. (1997). The Analects of Confucius (Trans.). W. W. Norton \& Company.

Liao, C-c. (1930). History of Chinese Political Thought: During the early Tsin Period. Harcourt, Brace.

Lu, X. (1998). Rhetoric in Ancient China, fifth to third Century B.C.E: A Comparison with Classical Greek Rhetoric. University of South Carolina.

Markham, J. (1994). Names and Actuality in early Chinese Thought. State University of New York.

Mei, Y-P. (1929). The Ethical and Political Works of Motes. Arthur Probsthan.

Mencius (1992). Mengzi bai-hua jin yi [the Translation of Mencius] Li Shuang (ed.). China Book.

Nakamura, H. (1964). Ways of Thinking of Eastern Peoples: India, China, Tibet, Japan. University of Hawaii.

Markham, J. W. (1967). Voices of the Red Giants: Communications in Russia and China Ames, Iowa. The Iowa State University. 
Michael, S. (2015). Confucius and the World he Created. Basic Books.

$\mathrm{Ng}$, R. E. C. (Forthcoming). Culture and modernization: the case of the People's Republic of China. In X. Lu, W. S. Jia, \& R. Heisey (Eds.). Chinese communication studies: Contexts and comparisons. Greenwood.

Northrop, F. S. C. (1946). The meeting of East and West. Macmillian.

Oliver, R. (1971). Communication and culture in ancient India and China. Syracuse University.

Oliver, R. (1989). Leadership in Asia. Univerity of Delaware.

Peng L. (1991). ZhouLi zhu-ti si-xiang yu cheng-sju nian-dai yan-jiu [the Study of central ideas of Zhou Li and its completion). China Academy of Social Science.

Philipsen, G. (1992). Speaking culturally: Exploration in social communication. State University of New York.

Porter, R., \& Samovar, L. (1988). Approaching intercultural communication. In L. Samovar \& R. Porter (Eds.), Intercultural communication: A reader, 5th ed. (pp. 15-31). Wadesworth.

Pye, L. (1985). Asian power and politics: The cultural dimensions of authority. Harvard University.

Pye, L. (1992). The spirit of Chinese politics. Harvard University.

Raphals, L. (1992). Knowing words: Wisdom and cunning in classical traditions of China and Greece. Cornell University.

SY (Shuo Yuan or the garden of talks) (1992). (Ed.). Liu Xiang, Guiyang: Guizhou People's Press.

Schuman, Michael (2015). Confucius and the world he created. Basic Books

Tan, F., \& Zhao, W. (1996). Highlights of da-zi-bao during the cultural revolution. Mirror Books.

Townsend, J. R. \& Womack, B. (1986). Politics in China. (3rd Ed.) Boston. 